\title{
PRODUCTION OF ELECTRICITY FROM AGRICULTURAL SOIL AND DYE INDUSTRIAL EFFLUENT SOIL USING MICROBIAL FUEL CELL
}

\author{
Samuel Raj. B ${ }^{1}$, Jebakumar Solomon. R.D ${ }^{2}$, Prathipa.R ${ }^{3}$, Anis Kumar.M ${ }^{4}$ \\ ${ }^{1 \& 2}$ Department of Molecular Microbiology, School of Biotechnolgy, Madurai Kamaraj University, \\ Madurai Tamilnadu jsolomon_mrna@yahoo.com,jarleumas@gmail.com \\ ${ }^{3 \& 4}$ Department of Biotechnology, PABCET,Tamilnadu, India.anik_biotech10@yahoo.com
}

\begin{abstract}
Microbial Fuel Cells (MFCs) or biological fuel cells are biochemical system that drives energy by mimicking bacterial interactions found in nature. It converts chemical energy into electrical energy without any combustion reactions being carried out. In our research, soil MFC was constructed and bioelectricity was harvested from two different types of soil samples such as agricultural soil and dye industrial effluent soil. The production of electricity was measured by using power measurements and it was compared for both the soil samples. The dye industrial effluent soil produced $0.93 \mathrm{~V}$ of electricity continuously for 650 hours whereas the agricultural soil produces $0.82 \mathrm{~V}$ for 400 hours.
\end{abstract}

Key words: Microbial Fuel Cells (MFC's), agriculture soil, dye industrial effluent soil, power measurement, electricity.

\section{INTRODUCTION}

Nowadays, Energy plays an important role in our life. Fossil fuels are depleted and the demand for alternative energy generation has an increasing trend. Renewable energy may be a suitable alternative for existing energy sources. Power generated from microbial fuel cell (MFC) is considered as renewable energy. MFCs provide new possibility for production of bio-energy from organic and inorganic sources [30]. The organic matters are converted to hydrogen in the presence of active biocatalysts in anode chamber under anaerobic condition. Generally, MFC consists of two compartments: an anaerobic anode and aerated cathode compartments in single chamber MFC. Microorganisms are used in MFCs to convert organic and inorganic compounds into bioelectricity. Pure or mixed culture of microorganisms can be used as biocatalyst in anaerobic anode chamber [21]. The concept of bioelectricity production was introduced in past few decades. Recently soil MFCs are effectively used in waste treatment and degradation of pollutions but application of MFC technology required more research in MFC construction and operation. In this work, applicability of soil MFC operation was checked in different soil sample to confirm the influence of soil in MFC technology.

\section{MATERIALS AND METHODS}

\subsection{Sample collection}

Two different types of soil samples were collected from two different sources namely $S_{1}$ soil sample collected from agricultural land and $S_{2}$ sample collected from dye industrial effluent soil near Madurai.The two samples were immediately sent to the laboratory for the inoculation of Soil MFC.

\subsection{Soil testing}

Soil testing has been accepted as a unique tool for rational fertilizer use. Soil testing is conducted to calculate the availability of nutrients to the plants, and to know the physical and chemical properties of the soil. The two soil samples S1 \& S2 were send to agricultural laboratory.

\subsection{Construction of SMFC}

In this work, Mudwatt Microbial fuel cell was used for the electricity production for both the $\mathrm{S} 1$ and $\mathrm{S} 2$ samples. (Keego Technologies LLC, Stanford, USA) Soil was patted down in MFC up to $1 \mathrm{~cm}$ to make a smooth surface and anode was placed on the top of the soil, finally soil sample was added up to $4 \mathrm{~cm}$ line. The cathode was placed on the top of the soil and the setup was closed using a lid. Electricity production was measured using digital multimeter.

\subsection{Power Calculation (Potential differences)}

The voltage across the external resistor in an MFC can be measured using a multi meter. Voltage measurements are converted to current values using Ohm's law:

$\mathrm{V}=\mathrm{I} \times \mathrm{R}$

Where $\mathrm{V}=$ voltage, $\mathrm{V}$

$\mathrm{I}=$ current, $\mathrm{A}$

$\mathrm{R}=$ resistance, $\Omega$

The power output from an MFC is calculated as

Where $\mathrm{P}=$ power, $\mathrm{W}$.

$$
\mathrm{P}=\mathrm{I} \times \mathrm{V}
$$

2.5 Isolation of Viable microorganisms from anode surface 
After the experiment was over, anode graphite fiber was removed from the Soil MFC and was kept for incubation in phosphate buffer solution for 1 hour in shaker and serial dilution was done by adding $1 \mathrm{ml}$ of phosphate buffer in $99 \mathrm{ml}$ of sterile water. $0.5 \mathrm{ml}$ aliquots of each serial dilution were transferred to agar plates by spread plating technique and were incubated at $37^{\circ} \mathrm{C}$ for 24 hours. After incubation, 20 different colonies were selected based upon colony morphology.

\subsection{Identification and characterization of organism}

\subsubsection{Colony Morphology}

The size and morphology of the bacterial colonies was determined by the help of an ocular and stage microscope.

\subsubsection{Gram staining}

Smear of the 12 colonies were made on slides and gram staining techniques was carried out.

\subsubsection{Genomic DNA isolation}

Genomic DNA was isolated by Sharma and singh method 2005. All the DNA sample was checked by running the sample in $0.8 \%$ agarose gel.

\subsubsection{S rRNA gene amplification}

16S rRNA gene was amplified using two specific universal primers 27F 5' - AGA GTT TGA TCC TGG TAC CTC AG 3' and 1492R 5' - GGT TAC CTT GTT ACG ACT T - 3' by PCR and the amp icons were resolved by electrophoresis in $1 \%$ agarose gel. The fragments were visualized under UV transilluminator.

\subsubsection{Polymerase Chain Reaction}

The 16S rRNA gene was amplified with $50 \mu$ reaction mixture containing $1 \mathrm{X}$ reaction buffer $(10 \mathrm{mM}$ Tris [pH 8.3], $50 \mathrm{mM} \mathrm{KCl}, 1.5 \mathrm{mM} \mathrm{MgCl2}$ ), $200 \mu \mathrm{l}$ dNTPs, $0.05 \mathrm{U}$ Taq DNA polymerase enzyme (Sigma, USA), $0.5 \mu \mathrm{M}$ each primer and $1 \mathrm{ng}$ template DNA. The thermal cycling conditions were: $5 \mathrm{~min}$ at $94^{\circ} \mathrm{C}$ for initial denaturation; 31 cycles of $30 \mathrm{sec}$ at $95^{\circ} \mathrm{C}, 1 \mathrm{~min} 30 \mathrm{sec}$ at $54^{\circ} \mathrm{C}, 2 \mathrm{~min}$ at $72^{\circ} \mathrm{C}$, and a final extension for $5 \mathrm{~min}$ at $72^{\circ} \mathrm{C}$.

2.6.5. Phylogeny identification of bacteria by $16 \mathrm{~S}$

\section{rRNA gene typing}

The sequences were compared with the 16S rDNA sequences available in the public databases from a BLAST search, and identified to the generic level. The sequences generated from the materials in this study, and retrieved from GenBank, were initially aligned using the CLUSTAL $\mathrm{X}$ program and the alignment then refined manually using version 3.0 of the PHYDIT program. A bootstrap analysis, using 1,000 replications, was performed to assess the relative stability of the branches.

\section{SEM ANALYSIS}

The morphologies of the anode and cathode surfaces were studied by using scanning electron microscope (SEM) (Hitachi, S570; Japan). The anodic samples were collected and fixed overnight with $2.5 \%$ paraformaldehyde and $1.5 \%$ glutaraldehyde in a buffer solution $(0.1 \mathrm{M}$ cacodylate, $\mathrm{pH} 7.5$ ) at $4{ }^{\circ} \mathrm{C}$, and then washed twice followed by stepwise dehydration in a gradient series of water/ethanol solutions $(25,50,70,85,95,100 \%)$, and then was critical-point dried (carbon dioxide). Samples were finally coated with $\mathrm{Au} / \mathrm{Pt}$ before SEM observation

\section{RESULTS AND DISCUSSION}

\subsection{Soil testing}

The two soil samples S1 and S2 were sent to soil plant analytical advisory centre, Department of soil and environment, Agriculture College and Research Institute, Tamil Nadu Agriculture university, Madurai and the result were shown in the table 1(a) and 1(b).

Table- 1(a): Soil testing report for agricultural soil

\begin{tabular}{|l|l|c|c|c|}
\hline \multirow{3}{*}{ Sample ID } & \multicolumn{1}{|c|}{ Parameter } & Unit & Value & Interpretation \\
\hline \multirow{4}{*}{ S1 } & $\mathrm{pH}$ & - & 8.12 & Normal \\
\cline { 2 - 5 } & $\mathrm{EC}$ & $\mathrm{ds} / \mathrm{m}$ & 0.05 & Harmless \\
\cline { 2 - 5 } & $\mathrm{KMnO}_{4}$ & $\mathrm{Kg} / \mathrm{ha}$ & 210 & Low \\
\cline { 2 - 5 } & Olsen-P & $\mathrm{Kg} / \mathrm{ha}$ & 80 & High \\
\cline { 2 - 5 } & $\mathrm{NNNH}_{4}-\mathrm{Ac}-\mathrm{K}$ & $\mathrm{Kg} / \mathrm{ha}$ & 1255 & High \\
\cline { 2 - 5 } & Organic carbon & $\%$ & 0.29 & Deficient \\
\cline { 2 - 5 } & DTPA Fe & $\mathrm{ppm}$ & 3.44 & Deficient \\
\cline { 2 - 5 } & DTPA Mn & $\mathrm{ppm}$ & 1.76 & Sufficient \\
\cline { 2 - 5 } & DTPA Zn & $\mathrm{ppm}$ & 2.09 & Sufficient \\
\cline { 2 - 5 } & DTPA Cu & $\mathrm{ppm}$ & 1.20 & \\
\hline
\end{tabular}


Table-1(b): Soil testing report for dye industrial effluent soil

\begin{tabular}{|l|l|c|c|c|}
\hline \multirow{3}{*}{ Sample ID } & \multicolumn{1}{|c|}{ Parameter } & Unit & Value & Interpretation \\
\hline \multirow{4}{*}{ S2 } & $\mathrm{pH}$ & - & 7.80 & Normal \\
\cline { 2 - 5 } & $\mathrm{EC}$ & $\mathrm{ds} / \mathrm{m}$ & 0.04 & Harmless \\
\cline { 2 - 5 } & $\mathrm{KMnO} 4$ & $\mathrm{Kg} / \mathrm{ha}$ & 73 & Low \\
\cline { 2 - 5 } & Olsen-P & $\mathrm{Kg} / \mathrm{ha}$ & 20 & Medium \\
\cline { 2 - 5 } & $\mathrm{NNNH}_{4}-\mathrm{Ac}-\mathrm{Kg}$ & $\%$ & 588 & High \\
\cline { 2 - 5 } & Organic carbon & $\mathrm{ppm}$ & 0.26 & Sufficient \\
\cline { 2 - 5 } & DTPA Fe & $\mathrm{ppm}$ & 6.62 & Sufficient \\
\cline { 2 - 5 } & DTPA Mn & $\mathrm{ppm}$ & 2.89 & Sufficient \\
\cline { 2 - 5 } & DTPA Zn & $\mathrm{ppm}$ & 2.14 & Sufficient \\
\cline { 2 - 5 } & DTPA Cu & & & \\
\hline
\end{tabular}

\subsection{Microbial Fuel Cell Design and construction}

Based on the procedure, the MFC was constructed as shown below and electricity was produced.

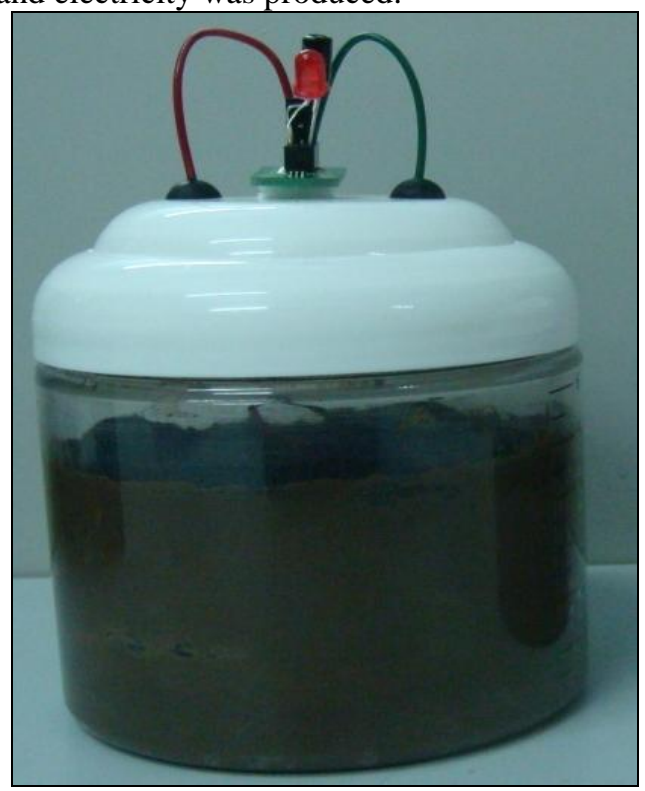

Fig-1: Single Chamber Microbial Fuel Cell

\subsection{Electricity production}

Soil Microbial fuel cell was designed by Keego Technologies LLC, a plastic container which is very cheap when compare to the other fuel cells. Soil MFC is capable of producing electricity more than 90 days continuously. Initially, when soil sample is inoculated in SMFC no electricity production has been obtained and after incubation for 48hours we observed increase in electricity production continuously. Finally based on the procedure the microbial fuel cell was constructed and electricity was produced. The MFCs were operated for $400 \mathrm{hrs}$ and the voltage produced using agricultural soil increased after $50 \mathrm{hrs}$ and then began to decrease after $360 \mathrm{hrs}$. (Fig-2) The dye industrial effluent soil was considered to result in the electrode potential and then an increase after 520 hrs. (Fig-3)

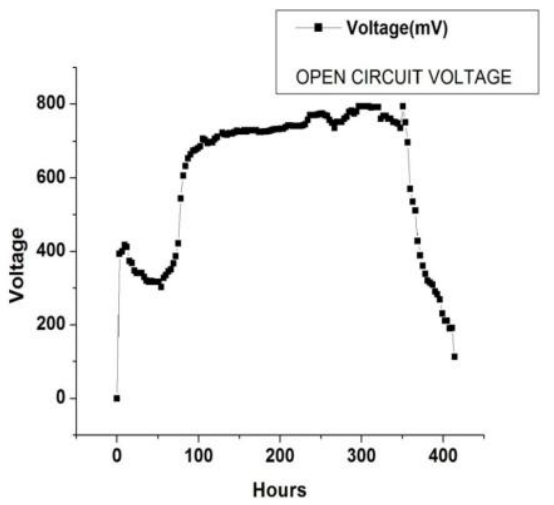

Fig-2: Graphical representation of voltage reading in agricultural soil sample

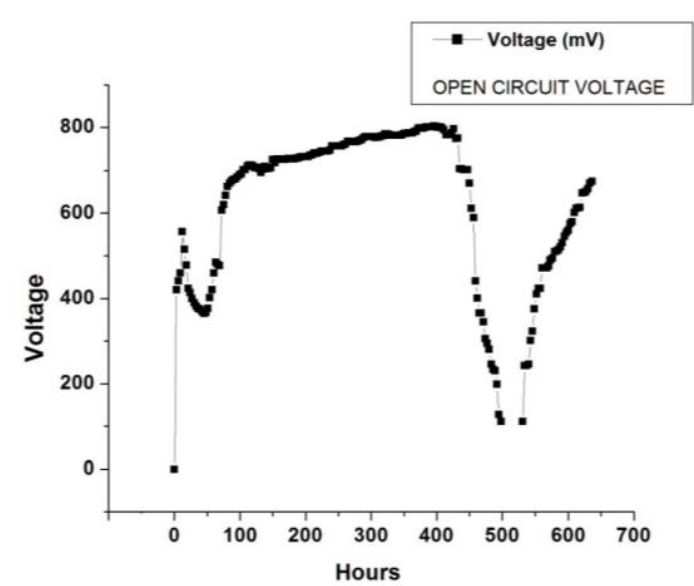

Fig-3: Graphical representation of voltage reading in dye industrial effluent soil sample.

\subsection{Isolation of microorganisms from the anode surface}

Isolated microorganisms grown on nutrient agar plates were sub cultured. The 12 different bacterial species were identified as Nitrobacter sp., Rhizobium sp., Gluconobacter sp., Bacillus sp., Stenotrophomonas sp., Escherichia sp., Proteus sp., Aeromonas sp., Azotobacter sp., and Pseudomonas sp. 

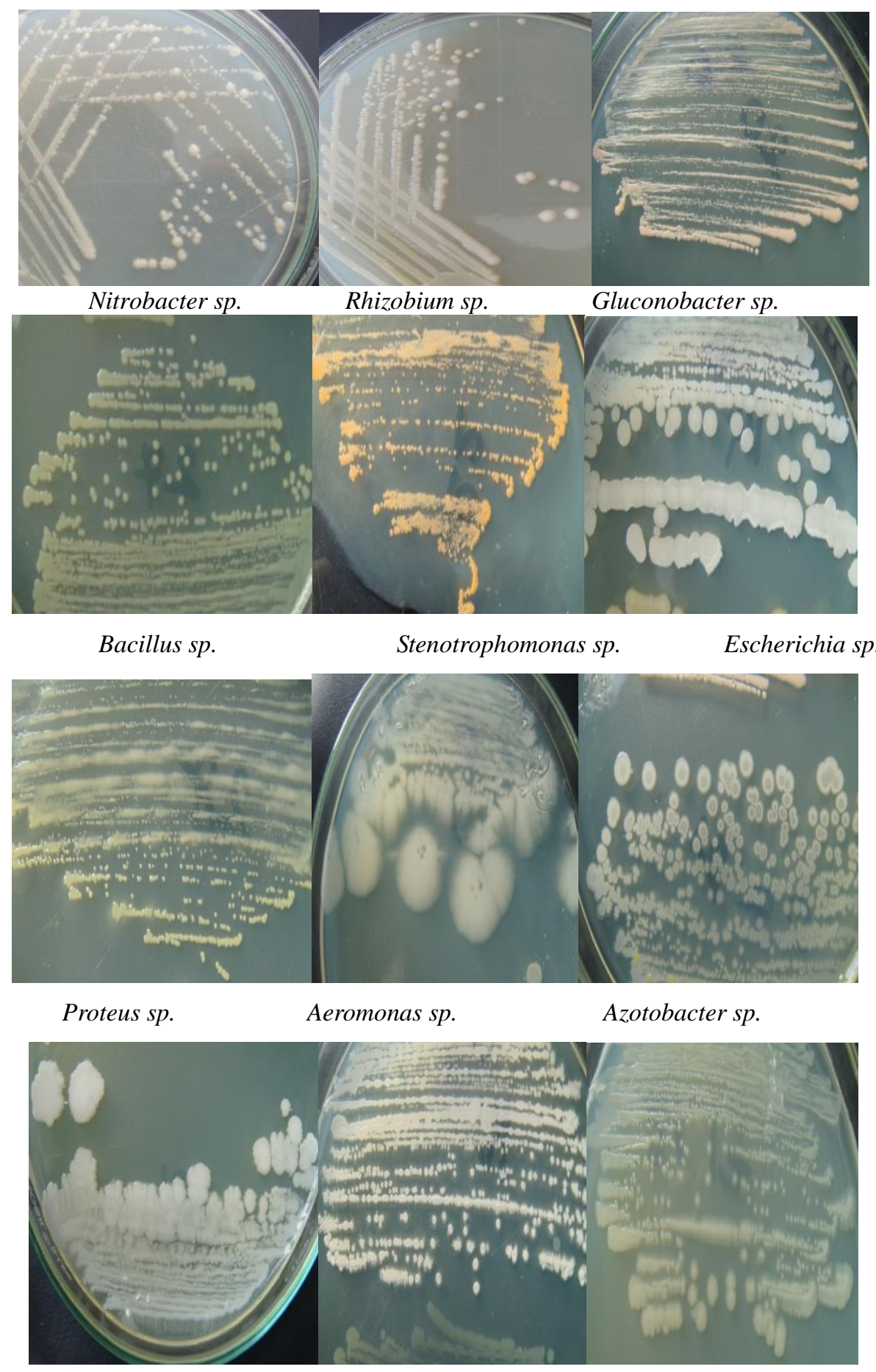

Pseudomonas sp.

Pseudomonas sp. Pseudomonas sp.

Fig-4: Isolation of viable microorganisms from anode surface 


\subsection{Gram Staining}

Gram staining was done for the 12 different bacterial species and the results were obtained as shown in table 2 .

Table -2: Gram's staining of 12 bacterial species.

\begin{tabular}{|c|c|c|c|}
\hline SPECIES & SHAPE & TYPE & BACTERIA \\
\hline Nitrobacter $s p$. & Rod & Gram negative & Facultative anaerobic \\
\hline Rhizobium sp. & Rod & Gram negative & Aerobic \\
\hline Gluconobacter sp. & Rod & Gram negative & Obligate aerobic \\
\hline Bacillus sp. & Rod & Gram positive & Obligate aerobic \\
\hline Stenotrophomonas sp. & Rod & Gram negative & Obligate aerobic \\
\hline Escherichia sp. & Rod & Gram negative & Facultative anaerobic \\
\hline Proteus sp. & Rod & Gram negative & Facultative anaerobic \\
\hline Azotobacter sp. & Rod & Gram negative & Aerobic \\
\hline Aeromonas sp. & Rod & Gram negative & Facultative anaerobic \\
\hline Pseudomonas sp. & Rod & Gram negative & Facultative anaerobic \\
\hline Pseudomonas sp. & Rod & Gram negative & Facultative anaerobic \\
\hline Pseudomonas sp. & Rod & Gram negative & Facultative anaerobic \\
\hline
\end{tabular}

\subsection{Genomic DNA isolation}

Genomic DNA was isolated by Sharma and singh method 2005. All the DNA sample was checked by running the sample in $0.8 \%$ agarose gel. (Fig. 5).

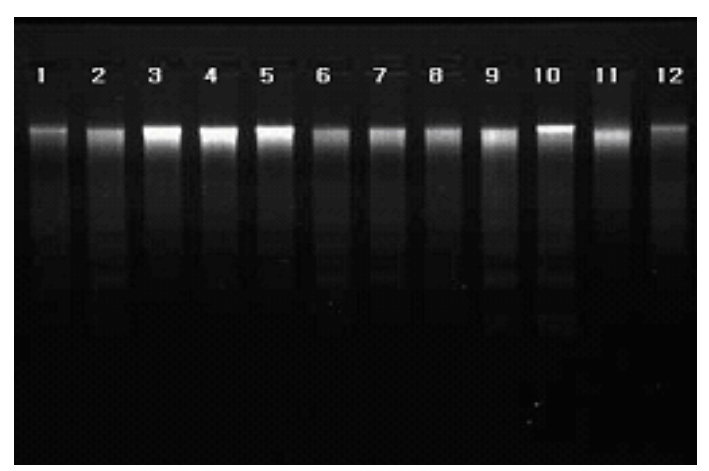

Fig - 5: Agarose gel showing the band of extracted genomic DNA from the 12 bacterial species.

\subsection{PCR amplification with Phylogenetic marker}

\section{gene primer}

PCR amplicons were resolved by electrophoresis in $1 \%$ Agarose gel to confirm the expected size of the product of 1500bp. The gel picture (Fig. 6.) shows all three templates were amplified of $1500 \mathrm{bp}$ size.

FP: 27F 5'-AGA GTT TGA TCC TGG

CTC AG-3'

RP: 1492R 5'-GGT TAC CTT GTT ACG

\section{ACT T-3'}

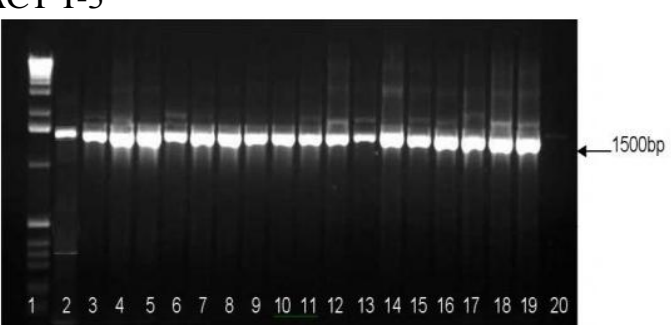

Fig-6: Agarose gel showing the band of amplified 16SrDNA of the 12 bacterial species and their size is $1500 \mathrm{bp}$.

\subsection{Phylogeny identification of bacteria by $16 S$ rRNA gene typing}

The taxonomy of the 12 different bacterial species was identified and the results were shown as follows. 


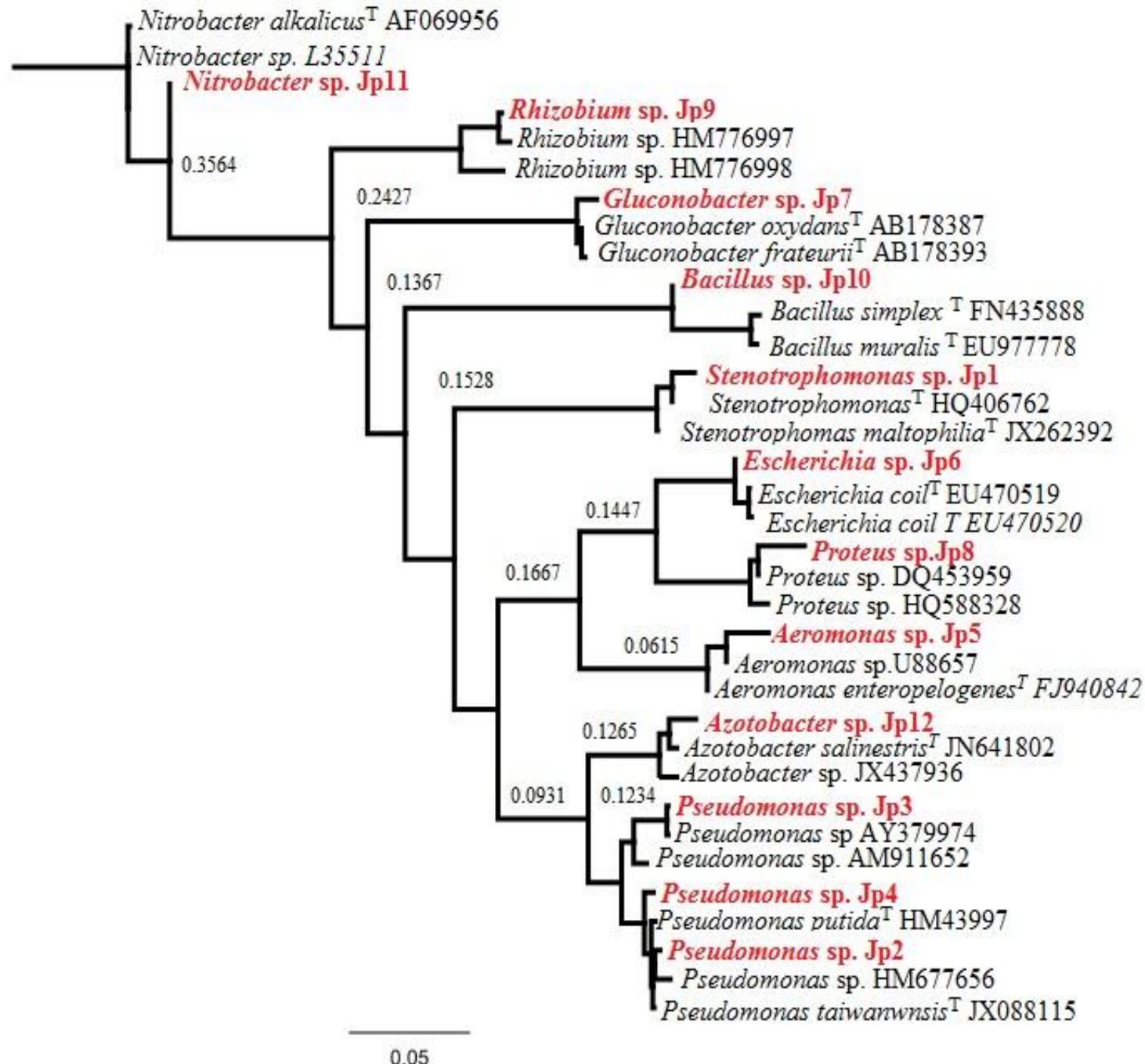

Fig- 7: Phylogenetic analysis of 12 bacterial species

\subsection{Analysis of SEM images}

The surface images of the graphite electrode were successfully obtained by SEM. The image from the surface of graphite electrode before and after experimental run was taken. The sample size was $1.5 \times 1.5 \mathrm{~cm}$ for SEM analysis. Figure 8.a. and 8.b. showed the outer surface of the graphite electrode prior to and after use in the MFC respectively. These images demonstrated that microorganisms were grown on the graphite surface as attached biofilm.

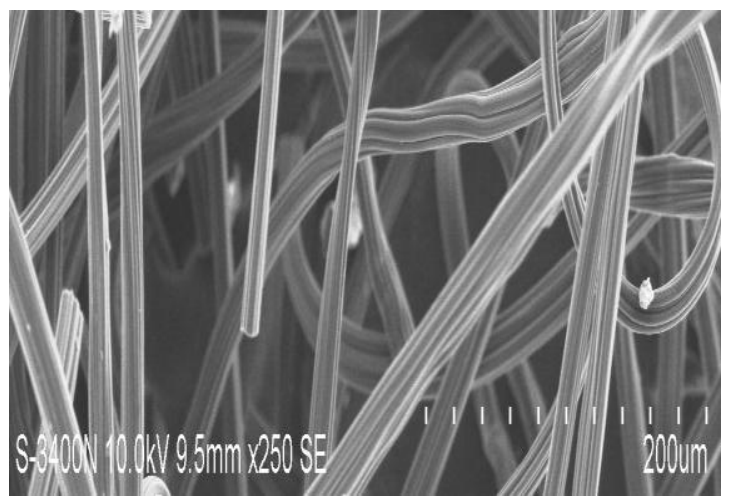

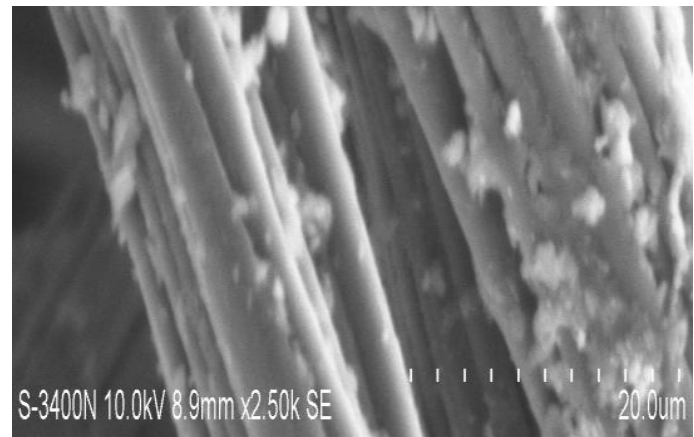

Fig-8: Scanning electron micrographs on carbon-based materials before and after biofilm formation. (a) Graphite fiber without biofilm (b) Graphite fiber with biofilm.

\section{CONCLUSION}

In conclusion, we found that soil MFCs constructed from the Industrial effluent soil are sustained in active, highly electrogenic bacterial anode community are present and capable of producing electricity continuously for 650 hours, whereas soil MFCs from agricultural soil produce electricity only 400 hours. These results shows the importance of soil type in MFC bacterial communities and this work will be 
helpful for the further research on soil MFC for long term electricity production. Interestingly, construction of MFC is important to achieve high power production using MFC technology thus Keego Technologies LLC resolved the problem of MFC construction. More research on industrial effluent soil and agricultural soil to study the exact mechanism in MFC is required.

\section{ACKNOWLEDGMENT}

This research was funded by the University Grants Commission, New Delhi, India under the UPE program to Madurai Kamaraj University.

\section{REFERENCES}

[1] Abhilasha, S. Mathuriya and Sharma, V.N. (2009) 'Bioelectricity production from paper industry waste using a microbial fuel cell by Clostridium species', J Biochem Tech Vol.1(2): pp.49-52.

[2] Aijie Wang, Dan Sun, Nanqi Ren , Chong Liu , Wenzong Liu, Bruce E. Logan, Wei-Min Wu. (2010) 'A rapid selection strategy for an anodophilic consortium for microbial fuel cells', Bioresource Technology Vol. 101, pp. 5733-5735.

[3] Allen, R. M. and Bennetto, H.P. (1993) 'Microbial Fuel Cells- Electricity Production from Carbohydrates', Appl. Biochem. Biotechnol, Vol. 39, No. 40, pp. 27-40.

[4] Anuradh Gunawardena, Sandun Fernando and Filip (2008) 'Performance of a Yeast-mediated Biological Fuel Cell', J. Mol. Sci. Vol. 9, pp.1893-1907.

[5] Bennetto, H.P. Stirling, J.L. Tanaka, K. and Vega, C.A. (1983) 'Anodic Reaction in Microbial Fuel Cells', Biotechnology and Bioengineering, Vol. 25, pp. 559-568.

[6] Booki Mina, Shaoan Chenga, Bruce E. Logan. (2005) 'Electricity generation using membrane and salt bridge microbial fuel cells', Water Research Vol. 39, pp. 1675-1686.

[7] Bruce E. Logan and John M. Regan. (2006) 'Electricity-producing bacterial communities in microbial fuel cells', Trends in Microbiology Vol.14, No.12.

[8] Bruce Logan, Berthamelers, Renerozendal, Uweschroder, Jurgkeller, Stefanofreguia, Peteralterman, Willyverstraete and Korneelrabaey. (2006) 'Microbial Fuel Cells: Methodology and Technology', Environmental Science \& Technology Vol. 40, No. 17.

[9] Bruce E. Logan. (2009) 'Exoelectrogenic bacteria that power microbial fuel cells', Microbiology Vol. 7

[10] Bruce E. Logan. (2011) 'Scaling up microbial fuel cells and other bioelectrochemical Systems', Applied Microbiology Biotechnology Vol. 85, pp. 1665-1671.

[11] Chae, K. J. Choi, M. Ajayi, F.F. Park, W. Chang, I.S and Kim, I.S (2008) 'Mass Transport though a Proton Exchange Membrane (Nafion) in Microbial Fuel Cells', Energy \& Fuels, 22, 169-176.
[12] Chen, T. Barton, S.C. Binyamin, G. Zhang, Y. Kim, $\mathrm{H}$ and Heller, A. (2001) 'Miniature Biofuel Cell', J. Am. Chem. Soc. Vol. 123, No. 35, pp. 8630-8631.

[13] Choi, Y. Jung, S and Kim, S. (2000) 'Development of Microbial Fuel cells using Proteus vulgaris', Bulletin of the Korean Chemical Society, Vol. 21, No. 1, pp. 44-48.

[14] Defeng Xing, Shaoan Cheng, John M. Regan, Bruce E. Logan. (2009) 'Change in microbial communities in acetate- and glucose-fed microbial fuel cells in the presence of light', Biosensors and Bioelectronics Vol. 25, pp. 105-111

[15] Fang Zhang, Shaoan Cheng, Deepak Pant, Gilbert Van Bogaert, Bruce E. Logan. (2009) 'Power generation using an activated carbon and metal mesh cathode in a microbial fuel cell', Electrochemistry Communications Vol. 11, pp. 2177-2179.

[16] Fang Zhang, Deepak Pant, Bruce E. Logan. (2011) - Long-term performance of activated carbon air cathodes with different diffusion layer porosities in microbial fuel cells', Biosensors and Bioelectronics Vol. 30, pp. 49-55.

[17] Farzaneh Rezaei, Tom L. Richard, Bruce E. Logan. (2008) 'Enzymatic Hydrolysis of Cellulose Coupled With Electricity Generation in a Microbial Fuel Cell', Biotechnology and Bioengineering Vol. 101, No. 6.

[18] Farzaneh Rezaei, Defeng Xing, Rachel Wagner, John M. Regan, Tom L. Richard, and Bruce E. Logan. (2009)'Simultaneous Cellulose Degradation and Electricity Production by Enterobacter cloacae in a Microbial Fuel Cell', Environmental Microbiology pp. 3673-3678.

[19] Gil G.C., Chang I.S., Kim B.H., Kim M., Jang J.Y., Park H.S (2003) 'Operational parameters affecting the performance of a mediatorless microbial fuel cell', Biosens Bioelectron Vol. 18, pp.327-334.

[20] Guangli Liu, Matthew D. Yates, Shaoan Cheng , Douglas F. Call, Dan Sun, Bruce E. Logan.(2011) 'Examination of microbial fuel cell start-up times with domestic wastewater and additional amendments' Bioresource Technology Vol. 102, pp. 7301-7306.

[21] Hong Liu, Shaoan Cheng, Liping Huang,, Bruce E. Logan. (2008) 'Scale-up of membrane-free single-chamber microbial fuel cells', Journal of Power Sources Vol. 179, pp.274-279.

[22] Joo-Youn Nam, Hyun-Woo Kim, Kyeong-Ho Lim, Hang-Sik Shin, Bruce E. Logand, (2010) 'Variation of power generation at different buffer types and conductivities in single chamber microbial fuel cells', Biosensors and Bioelectronics Vol. 25, pp. 1155-1159.

[23] Jung Rae Kim, Sok Hee Jung, John M. Regan, Bruce E. Logan. (2007) 'Electricity generation and microbial community analysis of alcohol powered microbial fuel cells', Bioresource Technology Vol. 98, pp. 2568-2577.

[24] Katz , E. Shipway, A. N. Wilner, I. Vielstich, W. Lamm, A. \& Gasteiger (2003) ' Handook of Fuel 
Cells-Fundamentals, Technology, and Application', pp. 355-382.

[25] Kim, B.H. Chang, I.S. Gil, G.C. Park, H.S. Kim, H.J (2003) 'Novel BOD sensor using mediator-less microbial fuel cell', Biotechnol. Lett Vol. 25, pp.541-545.

[26] Lee, H.S. Parameswaran, P. Kato-Marcus, A. Torres, C.I. and Rittman, B.E. (2008) 'Evaluation of energy-conversion efficiencies in microbial fuel cells (MFCs) utilizing fermentable and non-fermentable substrates', WaterRes.Vol. 42, pp.1501-1510.

[27] Liping Huang \& Bruce E. Logan. (2008) 'Electricity generation and treatment of paper recycling wastewater using a microbial fuel cell', Applied Microbiology Biotechnology Vol. 80, pp. 349-355

[28] Min, B. Cheng, S. and Logan, B. E. (2005) 'Electricity generation using membrane and salt bridge microbial fuel cells', Water Res. Vol. 39, pp.1675-1686.

[29] Oh S, Logan B.E (2005) 'Hydrogen and electricity production from a food processing wastewater using fermentation and microbial fuel cell technologies', Water Res Vol. 39, pp.4673-4682.

[30] Oh, S.E. Kim, J.R. Joo, J.H and Logan, B.E. (2009) 'Effects of applied voltages and dissolved oxygen on sustained power generation by microbial fuel cell', Water science and technology.

[31] Pant, Deepak, Van Bogaert, Gilbert, Diels, Ludo, Vanbroekhoven and Karolien (2010) 'A review of the substrates used in microbial fuel cells (MFCs) for sustainable energy production', Bioresource Technology ; Vol. 101, pp.1533-1543.

[32] Park and Zeikus, J.G (2003) 'Improved fuel cell and electrode designs for producing electricity from microbial degradation', Biotechnol. Bioeng. Vol. 81, pp.348-355.

[33] Patrick D. Kiely, Douglas F. Call, Matthew D. Yates, John M. Regan, Bruce E. Logan. (2010) 'Anodic biofilms in microbial fuel cells harbor low numbers of higher-power-producing bacteria than abundant genera', Appl Microbiology Biotechnology Vol. 88, pp. 371-380.

[34] Qian Deng, Xinyang Li, Jiane Zuo, Alison Ling, Bruce E. Logan (2010) 'Power generation using an activated carbon fiber felt cathode in an upflow microbial fuel cell' Journal of Power Sources Vol. 195, pp. 1130-1135.

[35] Roland D. Cusick, Patrick D. Kiely, Bruce E. Logan. (2010) 'A monetary comparison of energy recovered from microbial fuel cells and microbial electrolysis cells fed winery or domestic wastewaters', international journal of hydrogen energy.

[36] Sang Eun Oh, Bruce E. Logan. (2005) 'Hydrogen and electricity production from a food processing wastewater using fermentation and microbial fuel cell technologies', Water Research Vol. 39, pp. 4673-4682.

[37] Schroder, U. Niessen, J and Scholz (2003) 'A generation of microbial fuel cells with current outputs boosted by more than one order of magnitude' Angew. Chem. Int. Ed. Engl. Vol. 42, pp.2880-2883.

[38] Sebastià Puig, Marc Serra, Marta Coma, Marina Cabré, M. Dolors Balaguer, Jesús Colprim. (2010) 'Effect of $\mathrm{pH}$ on nutrient dynamics and electricity production using microbial fuel cells', Bioresource Technology Vol. 101, pp. 9594-9599.

[39] Shaoan Cheng, Hong Liu, Bruce E. Logan (2006) 'Increased performance of single chamber microbial fuel cells using an improved cathode structure', Electrochemistry Communications Vol. 8, pp. 489-494.

[40] Shaoan Cheng, Bruce E. Logan (2007) 'Ammonia treatment of carbon cloth anodes to enhance power generation of microbial fuel cells', Electrochemistry Communications Vol. 9, pp.492-496.

[41] Takefumi Shimoyama, Shoko Komukai, Akira Yamazawa, Yoshiyuki Ueno, Bruce E. Logan and Kazuya Watanabe (2008) 'Electricity generation from model organic wastewater in a cassette-electrode microbial fuel cell', Applied Microbiology Biotechnology Vol. 80, pp. 325-330.

[42] Valerie J. Watson, Bruce E. Logan (2011) 'Power Production in MFCs Inoculated with Shewanella oneidensis MR-1 or Mixed Cultures' Biotechnology and Bioengineering.

[43] Xiaoyuan Zhang, Shaoan Cheng, Xia Huang, Bruce E. Logan (2010) 'Improved performance of single-chamber microbial fuel cells through control of membrane deformation', Biosensors and Bioelectronics Vol. 25, pp. 1825-1828.

[44] Xiaoyuan Zhang, Shaoan Cheng, Xia Huang and Bruce E. Logan (2010) 'The use of nylon and glass fiber filter separators with different pore sizes in air-cathode single-chamber microbial fuel cell', Energy Environmental Science Vol. 3, pp. 659-664.

[45] Xin Wang, Shaoancheng, Yujiefeng, Tomonorisaito, and Bruce E.Logan (2009) 'Use of Carbon Mesh Anodes and the Effect of Different Pretreatment Methods on Power Production in Microbial Fuel Cells', Applied And Environmental Science Technology Vol. 43, pp. 6870-6874.

[46] Xin wang, Yujie feng, Heming wang, Youpengqu, Yanlingyu, Nanqiren, Nanli, Elle wang, Helee and Bruce Logan (2009) 'Bioaugmentation for Electricity Generation from Corn Stover Biomass Using Microbial Fuel Cells', Environmental Science Technology Vol. 43, pp. 6088-6093.

[47] Yi Zuo, Shaoancheng and Bruce Logan (2008) 'Ion Exchange Membrane Cathodes for Scalable Microbial Fuel Cells', Environmental Science Technology Vol. 42, pp. 6967-6972.

[48] Yongtae Ahn \& Bruce E. Logan (2012) 'A multi-electrode continuous flow microbial fuel cell with separator electrode assembly design', Applied Microbiology Biotechnology Vol. 93, pp. 2241-2248.

[49] Youngho Ahn, Bruce E. Logan (2009) 'Effectiveness of domestic wastewater treatment using microbial 
fuel cells at ambient and mesophilic temperatures', Bioresource Technology Vol. 101, pp. 469-475.

[50] Zhang, Z. Cheng, S. Wang, X. Huang, X. and Logan, B.E (2009) 'Separator characteristics for increasing performance of microbial fuel cells', Environ. Sci. Technol. Vol. 43, pp. 8456-8461. 